\title{
Social Media Usage for Enhancing English Language Skill
}

\author{
https://doi.org/10.3991/ijim.v14i07.11552 \\ E. Oos M. Anwas \\ Ministry of Education and Culture, Jakarta, Indonesia \\ Yuni Sugiarti \\ Syarif Hidayatullah State Islamic University, Jakarta, Indonesia \\ Anggraeni Dian Permatasari (凶) \\ Ministry of Education and Culture, Jakarta, Indonesia \\ anggraeni.dian@kemdikbud.go.id \\ Jaka Warsihna \\ Open University, Depok, Indonesia \\ Zulfikri Anas, Leli Alhapip, Heni Waluyo Siswanto, Rahmi Rivalina \\ Ministry of Education and Culture, Jakarta, Indonesia

\begin{abstract}
One of the obstacles of learning English Language as a Foreign Language is the limitation of practicing media. Social media has many contents and facilities which can be used for practicing English. The aim of this study is to find out students' intensity of using English-language social media content. The study was conducted by quantitative approach and survey method among the Senior High School students in Jakarta, Indonesia. Data analysis shows that as students' intensity who used English-language social media content is low. Stu-dents' perception of English skill in reading and writing is good, while students' perception of listening and speaking is still low. The intensity of using English-language social media content is positively and significantly related to students' perceptions of their ability to speak English including reading, writing, listening and speaking aspects. Hence, social media is needed to be learning media for learning English language as a Foreign Language in Indonesia.
\end{abstract}

Keywords-Social media, English language skill, English language learning media

\section{Background}

Learning language is mostly about practicing. Learning language is not only theoretical but also practical. It happens in every race and society around the world. For example, Indonesian people has their own vernacular. People who usually use own vernacular every day, are definitely able to speak their vernacular. Although they had not 
already learned vernacular formally or take a course but they are able to speak vernacular fluently. The Language skills are obtained from daily learning by direct practices. Beside that, both curriculum and learning process need to use ICT [44].

In fact, many Indonesian people have already learned foreign language like English language. But they do not use that for everyday language. So, it will be difficult for them to be able to master the language. Even though, they have learned while in formal school, they may take some courses but the result is, still they are not fluent in foreign language.

It happens to the Indonesian students while they learn foreign language, particularly English language. English language has been learned since the students are in junior high school or even in elementary school but the results are not optimal. In everyday life, the problem of practicing English is, most of the people use Indonesian language or vernacular. Unlike in Malaysia, Philippines, Brunei Darussalam and other former British colonies, English language becomes second official language after their own official language. The situation in Indonesia, English language is very rarely used.

The problems of English learning for students who have other languages was showed in the result of the study conducted by [29] in a private university in Indonesia. The study concluded with the problems identified in foreign language learning in English language education program are:

1. Learning process uses Indonesian language dominantly

2. Students' motivation to study and to be master in English is still low, and they feel shy and scared of making mistakes

3. Conducive foreign language learning environment for students has not yet been created

4. Time allocated by study program for practicing and learning English is not enough to support the development of language skills.

Another problem identified by [37] is time limitation to practice speaking in the class because the number of students is too large and there is no subjects and supplement technologies.

Mastering language, particularly foreign language like English is really needed to practice in reading, writing, speaking, and listening. These language skills can be done by internet usage as it has a lot of English language content.

The growth of internet usage in Indonesia is very fast. Internet is not only used in the cities but also in the villages. Nowadays, internet becomes a very important need of Indonesian people. There are about $50 \%$ people in Indonesia are connected with internet, knowing and using internet [24]. Every day, young people waste $70 \%$ of their time to access internet [25]. The high internet usage is realized because this technology has many elements of attraction and convenience. The growth of internet in reality has changed the pattern of life and people's mindset.

The internet is widely used to access social media. Social media usage intensity is increasing continuously. Indonesia is in the third rank in case of time wasted by people to access social media; it is about 3 hours and 21 minutes per day [25]. Social media usage by Indonesian people is relatively high. They use social media particularly for communication, entertainment and also for other needs. 
In accordance of time progress, social media is continue to grow with an offer of various facilities and advantages. According to [23], social media can be divided into six types. They are:

1. Social networks that have function to socialize and interact (facebook, linkedIn, myspace etc.)

2. Social media for discussion, chatting (skype, google talk, phorum)

3. Social media to share (media share) files including photos or videos (youtube, slideshare, feedback, instagram)

4. Media for publishing (wordpress, blog, Wikipedia, dig, wikia)

5. Micro blogging, a media for socializing but has a certain number of limits (twitter, plazes, plurk)

6. Social games, games that can be played together (doof, pogo, koongregate).

Variety of Social media gives various alternatives for users according to their needs. Social media is able to communicate verbally and in writing, also communicate directly (synchronous) or indirectly (asynchronous). Social media also can convey a variety of messages: text, photo, audio, video, animation, simulation, even interactive multimedia. Some of these social media contents use foreign language, particularly English language as an international language.

Learning through internet like social media according to [1] that using digital learning sources can improve writing skill of students. John and his co-authors showed that online learning can improve interaction and students' involvement (student centered learning). Specifically, according to [6], there was positive correlation and significance between student intensity of using English content on internet and student interest in English learning. [14] revealed that the students have positive perception about internet usage in language learning.

Social media is a form of internet network usage. For students, various types of social media contents and communication without geographical boundaries can be learning media to practice English. In other words, social media can be a medium to practice English. Practicing through social media can be conducted flexibly, everywhere and every time. The media can communicate cross geographical with everyone even communicate with native. The advantage of the media is minimalizing of shyness such as verbal communication in English. Social media can be used for daily practicing to improve English skills. The problem is whether the use of English in social media content has a relationship with English language skills.

The aims of this study are to find out: 1) students' intensity in using English social media content; and (2) intensity of relationship between using English social media content and students' perception to their English skills. English language skills include skill in reading, writing, listening, and speaking. 


\section{$2 \quad$ Literature Review}

\subsection{Social media characteristics}

Nowadays, social media has changed the way how people communicate, convey ideas and connect to others. There are some reasons why social media is also popularly used in the field of education, such as it is used by students and the people widespread; it offers a characteristic that other teaching media doesn't have; and more importantly, it also brings some changes towards the conventional value and concepts of students' learning process [19].

The context of social media most commonly only focuses on the daily stories told based on someone's experience, a debate whether a story is important to be discussed or not, and other social sources that create both speaker's and audience's identity. Social media is also used to document an event that an account owner is experiencing at the moment. A story published in social media might sometimes be something emotional that has a deep meaning for the account owner [32].

Social media is different from mass media in some ways. The information published in social media usually attracts more attention and reaches to a bigger scope of audience compared to the one in mass media. Being aware of this fact, mass media often uses social media as a tool to promote itself. Media industry also uses social media to report the newest news happening [17]. Social media users are not limited to a particular location and a nation's geographical borders.

Social media users are not only passively receiving information but also can actively create a content and share it online. This is what makes social media users can act as both, a consumer and a producer [9]. The content accessed from social media is varied; it can be in the form of texts, photos, audio, videos, animation, simulations, etc. According to [8], a content on social media can be used as a business commodity. These various contents on social media can be easily accessed by using a handphone or any gadgets. This is what makes social media very flexible to be used by different individuals with different needs, potency and desires. Ethically and lawfully, the use of social media fully depends on each of its user [31].

Social media also offers the possibility for the users to have a two-way communication. This communication uses the social media's network itself, which is more popularly known as viral communication that is a public conversation among online users. Viral community is a group of any individuals with no limitation in terms of their time, place, physical condition, or even economical status [31].

\subsection{Learning English as a foreign language}

The teaching of English as a foreign language requires an effective strategy which could help students understand the language better. Ideally speaking, the teaching of English in the classroom must not only cover theoretical knowledge but also practices on how to use the language properly related to the topic being taught. This idea of providing sufficient language practice is supported by the results of previous studies. 
Reference [5] once conducted an interview related to the PPP (Presentation, Practice, and Production) framework in English language teaching. PPP is a framework of English language teaching proposed by Byrne (1976). Regarding this framework, the aspect of practice plays an important role during the learning process as it helps students to understand the materials better and store it in their long-term memory.

A study conducted by [30], investigated whether there is a significant long-term effect on applying repetition method towards Japanese students' English vocabulary understanding. The result of the study revealed that repeating the vocabulary from five up to seven times significantly contributes to the higher score achieved by the students. Thus, it can be said that the more the students practice the language, the better their understanding towards the language will be.

Giving sufficient time to practice writing in English will help students to be a more proficient English writer. As reported in a study conducted by [36] which finds that students in the University of Golestan, Iran successfully improved their writing skill after they have been given some time to practice writing a journal. The result of the study shows that writing a journal gives a positive impact towards the students' grammar and confidence in writing.

Reference [35] even strengthen the idea on how sufficient practice can help to improve students' language (English) ability. [35] conducted a study about the effect of using podcast on improving students' listening skill in SMA N 1 Luwu. The result of the study reported that the students taught using podcast achieved better score in listening, compared to those students taught using conventional method.

Reference [10] conducted a study on how practice of speaking outside the classroom could improve the third-grade students' speaking skill in Turkey. The result of the study showed that the students who have more interactive recording significantly improved their speaking skill compared to those who do not, even though based on the result of the pre-test, the students in the experimental group was having lower speaking score compared to the students in the control group. Moreover, the students in the experimental group also improved their ability in responding a question more confidently with less frequent hesitation.

Reading skill can also be improved by having sufficient practice as it is reported in a study conducted by [39] which investigated the effect of blogging on students' reading skill. Based on the result of their study, it is found that blogging can help to improve the students' reading skill.

There have been some studies conducted on the strategy used in teaching English. Reference [16] conducted a study on the effectivity of using mobile application designed within cognitive domain on facilitating students to face difficulties in learning English as a foreign language. The result of the study reveal that the use of mobile application can improve the learning of English as a foreign language. The application designed is approved to be an effective tool for learning English, though regarding to the students' perception, this application still needs some modifications to make it more adaptable.

Reference [4] conducted a study on the strategies used by teachers in Brunei Darussalam to develop students' interest in learning English as a foreign language. The subjects of the research were the fourth-grade students and English language teachers. The 
study revealed that there are some strategies applied, such as using ICT (Information and Communication Technologies), music and media. The result of the study reported that $90 \%$ of the students agreed that the use of ICT and music can help to facilitate English teaching and learning process. Meanwhile, according to the English language teachers, there are various strategies that can be applied in English teaching and learning process, such as books, cards, posters, and ICT.

Informal English learning can be done in a number of ways. One of the most popular ways is to access any English learning sources online. In a study conducted by [21], it is found that Slovenian students prefer accessing English materials online to improve their receptive skills to productive skills.

Some related studies on the use of social media to support the process of learning English as a foreign language have been conducted in some countries. [38] conducted a study on university students' perception on using social media to learn English in STKIP Muhammadiyah Rappang. Based on the result of the research, it is found that students show positive attitude and willingness to use social media in writing class. However, there are some problems that might be barriers for students in using social media such as large classes, lack of training on the use of the internet, and the lack of facilities.

A study on the effect of social media towards English learning has been conducted by [40]. This study aimed to investigate the use of Facebook in enhancing the effectivity of English learning among English language teachers. The result of the study indicated that Facebook can be used to improve writing skills, namely accuracy, meaningfulness, clarity and relevance. Additionally, it can also enhance fluency, self-confidence, satisfaction and value.

Social media has been proven to be able to help university students in Khyber Pakhtunkhwa to improve their English language skill that revealed through a study conducted by [26]. This study reported that the use of social media (Facebook, Twitter, Flicker, WhatsApp, and Skype) can improve the students' English language skills, namely listening, speaking, reading, writing, and language components: namely vocabulary and grammar.

The effectivity of utilizing social media to learn English as a foreign language also has been studied by [2]. The subjects of his study are four-year students majoring B.A. in English at Al Ardh college of Science and Arts for girls in Jazan University, Saudi Arabia. The result of the study conveyed that utilizing social media (i.e. Twitter, Facebook, Youtube, and WhatApp) greatly helps the teaching and learning process which later influence the students' success in learning English as a foreign language.

Another study in the same area of interest has also been conducted by [7]. In this study, the researcher only highlighted the influence of social media in tertiary-level students' speaking and writing. The result of this study found that social media has positively affected the students' as well as the teachers' speaking and writing skills through group discussions where they can exchange their ideas, access to easily sharing course-related materials and assignments.

Reference [13] has also studied the influence of Facebook group in enhancing the ninth-grade female students' writing skill in Al Rahedia, Jordania. From the result of 
this study, it is found that Facebook can be used to motivate the students to actively participate and be more enthusiastic in practicing English writing skill.

The last but not the least, a study on the effect of using Facebook to improve twoyear students' writing skill as well as enriching their vocabulary in the University of Jordania. The result of this study revealed that the students taught writing using Facebook achieve better score and have richer vocabulary compared to those students taught using conventional method [3].

\section{Research Method}

This research in accordance with the purpose of the research was conducted by quantitative approach with survey method. The study was conducted among the students of Senior High School in Jakarta, Indonesia. Target population was students in Senior High School in Jakarta, Indonesia. Sample was taken by random sampling technique and the total number of samples were 185 students. Data collection was conducted on March, 2018.

Data collection was conducted using questionnaires. Students filled research questionnaires by internet network using google drive. Variable studied were intensity of students using English social media content and the relationship with students' perception to their English skills. English language skills include reading, writing, listening and speaking. The skills were measured based on perception of each student.

Data collected then was analyzed using descriptive statistics and correlation statistics of Spearman's. SPSS version 23 was used to facilitate data processing. Research questions were expected to be answered by data analysis.

\section{$4 \quad$ Finding and Discussion}

This study highlighted the correlation between the senior high school students' intensity in accessing an English content on social media and their English language skills. The aspect of social media use covers: the intensity in accessing social media, the contents accessed, and the source of the contents. English language learning consists of four language skills: listening, speaking, reading and writing. The term social media in this study refers to Line, WhatsApp, Instagram, Facebook, Twitter, Snapchat, Ask.fm and the like. Table 1 below presents the result of questionnaire related to the use of social media.

Table 1 Intensity of English Social Media Usage

\begin{tabular}{|c|c|c|c|}
\hline Number & Intensity & $\mathbf{F}$ & $\mathbf{\%}$ \\
\hline 1 & Very rare & 31 & 16.8 \\
\hline 2 & Rare & 123 & 66.5 \\
\hline 3 & Often & 26 & 14.1 \\
\hline 4 & Very often & 5 & 2.7 \\
\hline
\end{tabular}


Basically, the students' intensity in accessing English contents on social media is still low. From Table 1, it can be seen that there are only $17 \%$ of the students who accessed English content on social media very often. On the contrast to this finding, a study conducted by [12] reported that the intensity in accessing social media among teenagers in Jakarta is high. More importantly, there is also a great number of English contents available on social media that the students can easily access. Regarding to this finding, it can be concluded that the students dominantly access social media contents created using Indonesian or local languages. In other words, the students' ability in using English is still low.

Table 2 Type of English Social Media Content Accessed

\begin{tabular}{|c|c|c|c|}
\hline Number & Type of content & f & \% \\
\hline 1 & Video/animation & 168 & 90.8 \\
\hline 2 & Text & 130 & 70.3 \\
\hline 3 & Audio & 131 & 70.8 \\
\hline 4 & Simulation & 16 & 8.6 \\
\hline
\end{tabular}

Table 2 presents that $90.8 \%$ of the English contents accessed by the students are in the form of video or animation. The result of the interview with some subjects of this study revealed that social media contents carried out in the form of videos or animations are more exciting to watch and easier to understand since the messages are created in the form of moving visual images completed with an audio. The content of a video is varied. It can be in form of songs, movies, documentary files, or even learning materials. Moreover, almost all social media applications launched recently offer easy features to record a video, edit a video, upload a video, and share a video instantly. Even the two-way communication on social media nowadays also allow us to enjoy a video call.

Another finding that can be obtained from Table 2 is the high number of contents uploaded in the form of texts and audio. The contents created in the form of text and audio also plays a great favor in improving the students' ability to use English. Audiovisual contents offer a perfect example on how to pronounce English words correctly since they are not pronounced the way they are spelled. In this case, students can also visually see on how the speaker's lips move in order to produce the correct pronunciation. Thus, from the audio-visual contents, students are expected to be able to practice their English pronunciation. Then, from the contents created in the form of text, students are expected be able to practice their reading and learn how to write grammatically correct sentences.

Table 3 English Content Type Accessed

\begin{tabular}{|c|c|c|c|}
\hline Number & Content type & F & \% \\
\hline 1 & Songs & 167 & 90.3 \\
\hline 2 & Films & 135 & 73.0 \\
\hline 3 & Games & 81 & 43.8 \\
\hline 4 & Subjects & 79 & 42.7 \\
\hline 5 & News & 28 & 15.1 \\
\hline
\end{tabular}


From the various form of contents available on social media, songs get the highest interest from the students. Based on the data presented on Table 3, there are $90.3 \%$ of the students who accessed English songs on social media. Relating this finding to the data presented in Table 2, it can be concluded that the most frequently accessed English songs are uploaded in the form of videos or animation. This finding goes hand by hand with the advanced technology development which offer an easy access to enjoy songs in mp4 format on Youtube or any other application.

Not only accessing English songs, 73\% of the students also enjoy accessing English movies. Students can enjoy English movies as an entertainment and also a way to practice their listening skills. Just like English movies, video games also offer the same advantage for the students.

Additionally, based on the data presented in Table 3, it can be seen that there are $42.7 \%$ of the students who accessed learning materials on social media. This indicates that social media is a great option to be used as a media in the English teaching and learning process.

Lastly, it is found that there are $15.1 \%$ of the students who accessed English news on social media. This is not something surprising since students on this age are commonly more interested in songs, movies, games, or learning materials. From the data presented in Table 3, we can conclude that teenagers use social media for various purposes. As it is reported in a study conducted by [41] that teenagers use social media for information, virtual communication, hobbies exploration, entertainment, fashion, lifestyle, and even online learning.

Social media these days has been equipped with advanced technology which allows users to multitask feature. Through this multitasking feature, users can execute some work in an instant method and at the same time. The characteristic of this feature fits perfectly with the characteristics of millennials who want everything to be done quickly and instantly. For example, when students do their homework using a laptop, they can have a discussion with their friends on Whatsapp, can have a video call on Skype, listen to the music on Youtube, and many others at the same time. All these activities can be done at the same time by utilizing social media.

Despite the abundant benefits that social media offers, there are some teenagers who have terrible experiences in using social media. According to a study conducted by [41], the terrible experiences that social media users will possibly experience are hacked by a hacker, stiff neck, eyes irritation caused by accessing social media in such a long period of time, being ignored while talking to friends, being judged through the comments section, being scammed to purchase fake products, inflicting jealousy caused by misunderstanding, and being influenced by any hoax shared on social media. Therefore, it is important to be wise and really careful in accessing social media specifically for students.

Related to [41] and [33] also suggested that although mobile applications are currently developing rapidly, it is still difficult to find the right application for education purposes. Although the application was declared as an educational application.

Other studies which related to that findings have also been conducted by [34] and [22]. The mobile application for Greek preschoolers designed to teach children about numbers and letters turns out to be based only on low level thinking, rote learning, and 
does not contribute to conceptual understanding. Mobile applications which are suitable for development needs of preschoolers can be found hardly.

Table 4 English Content Resources in Internet

\begin{tabular}{|c|c|c|c|}
\hline Number & Address of Content & F & \% \\
\hline 1 & Looking for by themself & 177 & 95.7 \\
\hline 2 & Friends & 170 & 91.9 \\
\hline 3 & Teachers & 6 & 3.2 \\
\hline 4 & Parents & 2 & 1.1 \\
\hline
\end{tabular}

Students in this globalization era are popularly called as digital native. Digital natives are people who are very familiar with the use of computers and internet from an early age in which most of the time they do not need to read a manual book to operate a new tool. They are able to directly search for and find out what they need using internet and social media, it can be seen in Table 4 that $95.7 \%$ of the students are able to find English learning materials on internet on their own. Meanwhile, some other students also claim that they find the source of English learning materials from friends' recommendation.

Parents and teachers play an insignificant role in helping students in order to find the source of English learning materials accessed on the internet. In respect of the great enthusiasm that students have access to English learning material on the internet, parents and teachers should have been properly informed on how to guide and help students using internet for educational purpose optimally. As supported by the result of a study conducted by [12] that parents and teachers play a positive and significant role in the use of internet as students' learning sources. In this case, parents and teachers can share the links of any websites that provide English learning materials.

Specifically, for teachers, they can fulfil their role in utilizing internet to facilitate English learning by assigning some tasks and exercises for students. The demand to search for the links that provide English learning materials should not only be burdened to the English teachers but also all teachers who teach other subjects.

As for parents, they can fulfil their role by monitoring what their children are accessing from the internet. Parents should filter the contents accessed by their children and even give suggestions and recommendations about the links that the children should access, preferably educational websites. In this case, parents are highly suggested to be able to understand whether the website provides relevant English learning materials and be able to enrich their children's knowledge or not.

There are four language skills that students should be able to acquire in learning English as a foreign language, namely listening, speaking, reading, and writing. From Table 5, it can be seen that the students' reading skill is good. There are $51.9 \%$ of the students who claim that they are able to read English texts well and even 9.2\% of them claim that their English reading skill is very good. These findings indicate that the students are able to comprehend English texts well. However, there are 39\% of the students who claim that they still experience some difficulties in comprehending English texts. Therefore, parents and teachers should give their best efforts in helping senior high school students to improve their reading skill in English. 
Paper-Social Media Usage for Enhancing English Language Skill

Table 5 Students' Perception Towards English Language Skills

\begin{tabular}{|c|c|c|c|c|c|}
\hline Number & Categories & Reading (\%) & Writing (\%) & Listening (\%) & Speaking (\%) \\
\hline 1 & Very lack & 2.7 & 2.7 & 7.6 & 4.3 \\
\hline 2 & Lack & 36.2 & 43.2 & 58.9 & 53.0 \\
\hline 3 & Good & 51.9 & 51.4 & 30.8 & 40.5 \\
\hline 4 & Very good & 9.2 & 2.7 & 2.2 & 2.2 \\
\hline
\end{tabular}

Next, for the students' writing skill, it can be seen that there are more than $50 \%$ of the students who claim that they are able to write well in English and even $2.7 \%$ of them claim that their English writing skill is very good. However, there are $45.9 \%$ of the students who claim that their writing skill is poor and even some of them claim to have a very poor English writing skill. Having a closer look to the results of the students' reading and writing skills, it can be seen that both data is similar to each other. The similarity between the two, might indicate that there is a correlation between the students' reading and writing skills.

Then next, for the students' listening skill, it can be seen that there are $68 \%$ of the students who claim that they have a poor listening skill and even some of them claim that their listening skill is very poor. These indicate that most of the students still experience difficulties in understanding spoken English information. There are only 30.8\% of the students who claim to have a good listening skill and $2.2 \%$ of them who claim to have a very good listening skill. Thus, it can be concluded that the students' listening skill is lower than their reading and writing skills.

Lastly, on the students' speaking skill, it can be seen that there are $58 \%$ of the students who claim that their speaking skill is poor and even some of them claim that their speaking skill is still very poor. This means that most of the students still experience difficulties in conveying their ideas in English.

Comparing all the four skills that the students have, it can be concluded that the students' skill in reading and writing are better than their skill in listening and speaking. In other words, it can be said that the students' skills in passive activities like reading and writing are better than their skills in active activities like listening and speaking.

Speaking is one of the most important skills to be acquired in a language learning. According to [28] and [20], the success of learning a language can be measured from the students' ability to speak and use the language learned properly. The students' poor speaking skill in English should become a great concern for parents, teachers, and other related authorities.

\subsection{The correlation between variables}

To analyze the correlation between the students' intensity in accessing social media and their English language skills, the researcher applied a correlation analysis. The result of the analysis shows that there is a positive and significant correlation between the students' intensity in accessing social media and their English language skills. In the data presented in Table 6, it is shown that the students' four language skills (reading, writing, listening, and speaking) are positively and significantly correlated to their intensity in accessing social media. 
Table 6. Correlation between English Social Media Content Usage and Perception to English Language Skills

\begin{tabular}{|c|c|c|c|}
\hline Number & Language skills & R & sig \\
\hline 1 & Reading & .332 & $0.000^{* *}$ \\
\hline 2 & Writing & .289 & $0.000^{* *}$ \\
\hline 3 & Listening & .190 & $0.000^{* *}$ \\
\hline 4 & Speaking & .336 & $0.000^{* *}$ \\
\hline
\end{tabular}

Based on the data presented in Table 6, it can be seen that there is a positive and significant correlation between the students' intensity in accessing English contents on social media and their reading skill. The correlation and coefficient between the two variables is 0.332 using $0.01(99 \%)$ level of significance. Regarding these findings, it can be interpreted that the higher the students' intensity in accessing English contents on social media, the better their reading skill will be or the other way around.

For the writing skill, the data shows that there is a positive and significant correlation between the students' intensity in accessing English contents on social media and their writing skill. The correlation and coefficient between the two variables are 0.289 using $0.01(99 \%)$ level of significance. Regarding this finding, it can be interpreted that the higher the students' intensity in accessing English contents on social media, the better their writing skill will be or the other way around. As supported by the result of the study conducted by [27] which reports that the use of Facebook can motivate the students to write and improve their recount text writing skill.

For the listening skill, the data shows that there is a positive and significant correlation between the students' intensity in accessing English contents on social media and their listening skill. The correlation and coefficient between the two variables is 0.190 using 0.01 (99\%) level of significance. Regarding this finding, it can be interpreted that the higher the students' intensity in accessing English contents on social media, the better their listening skill will be or the other way around.

For the speaking skill, the data shows that there is a positive and significant correlation between the students' intensity in accessing English contents on social media and their speaking skill. The correlation and coefficient between the two variables are 0.336 using 0.01 (99\%) level of significance. Regarding this finding, it can be interpreted that the higher the students' intensity in accessing English contents on social media, the better their speaking skill will be or the other way around.

The result of the correlation analysis indicates that practicing speaking by using social media is very practical to be done since social media has a wide range of audiovisual contents. Moreover, according to [20], practicing speaking by using social media might lower the influence of the psychological factors, such as sacred of making mistakes, shyness, nervousness, low self-confidence, and lack of motivation that might hinder the students to speak English in class.

The data presented in Table 6 shows that the students' intensity in accessing English contents on social media is positively and significantly related to the students' reading, writing, listening and speaking skills in 0.01 (99\%) level of significance. Regarding this finding, it can be interpreted that the higher the students' intensity in accessing English contents on social media, the better their reading, writing, listening, and speaking skills 
will be. On the other hand, the lower the students' intensity in accessing English contents on social media, the worse their reading, writing, listening, and speaking skills will be.

Relating to the result of the correlation analysis to the data presented in Table 1, it can be concluded that the students' English language skills are still poor because their intensity in accessing English contents on social media is low even though it is known that the students frequently use social media on their daily basis. Therefore, these students need a strong motivation on how to use social media as a source to learn the four English skills, namely reading, writing, listening and speaking.

The result of the correlation analysis in this study shows a coherent result to the previous studies. Reference [6] stated that students can practice speaking in English with friends, teachers, parents, or whoever by using e-mail, video call, or social media (i.e. Facebook, WhatsApp, Twitter, Instagram, etc.). The study conducted by [14] finds out that students show positive attitude towards the use of internet as a source of language learning. Another study conducted by [38] reported that the use of social media is very helpful for students; it is very easy for students to find references from open access to journal and e-book to finish their assignments. Moreover, by using social media, students are also able to communicate with people from around the world which will be a good chance for them to practice their English. Lastly, the result of the study conducted by [15] explained that the use of social media helps students' language learning process as students are able to communicate with people from other countries using the international language, English. Students can use various advanced applications to be able to communicate with people worldwide in their fingertips.

\section{$5 \quad$ Conclussion and Suggestions}

Generally, the students' intensity in using English-language social media contents is still low. The English-language social media contents that are most often accessed are in the form of video/animation, text and audio. The types of English-language contents that are mostly accessed are in the form of songs, films, games and school lessons. Then almost all of students said that looking for address of English-language contents by themselves and from their friends.

Generally, the students' perceptions towards English proficiency in the aspects of reading and writing are in the good category. On the other hand, the students' perception towards English proficiency in the aspects of listening and speaking are still in the bad category. Less than a half of the students said good at listening and speaking English. It is homework for parents and teachers to look for improvement and solution.

Generally, the intensity of using English-language social media contents is positively and significantly related to students' perception of their English proficiency. Likewise, specifically the intensity of using English-language social media contents is positively and significantly related to students' perception of their aspects of reading, writing, listening and speaking. The students' low intensity in accessing English-language social media contents is significantly related to the students' low perception of their English proficiency. 
The implication of the study is that learning foreign languages specifically English in countries where the mother tongue is not English needs to use social media. Social media is currently used by many students in various countries and they can communicate in English as a foreign language practice in their country.

The result of this study suggests that the students need to be encouraged by using English-language social media contents in order to improve their English proficiency. It is known that there is significant relation between use of social media content and English proficiency. So, the use of social media is much needed in learning English. Types of social media are very diverse. Likewise, the contents and other facilities can attract millennial generation as a place to practice, practice and habituation in learning English.

To improve the use of English-language social media contents in the students' environment, the role of teachers and parents is very important. The students need to be given assignments, guidance, and habituation step by step and continuously. In the end, the use of English-language social media contents expected to become a culture and medium for learning English in countries like Indonesia, because it is a foreign language.

\section{$6 \quad$ References}

[1] Aberg, E. S., Stahle, Y., Engdahl, I, Nyqvist, H.K. (2016). Designing a Website to Support Students Academic Writing Process. TOJET: The Turkish Online Journal of Educational Technology, 15(1), pp. 33-42.

[2] Al-Mubarak, A.A. (2016). Learning English as a Second Language through Social Media: Saudi Arabian Tertiary Context. International Journal of Linguistics Vol. 8 No. 6, pp. 112127. https://doi.org/10.5296/ijl.v8i6.10449

[3] Al-Tamimi M.F., Al-Khawaldeh, A.H., Al-Natsheh, H.I.M., Harazneh, A.A. (2018). The Effect of Using Facebook on Improving English Language Writing Skills and Vocabulary Enrichment Among University of Jordan Sophomore Students, Journal of Social Sciences Vol. 7 No. 3. https://doi.org/10.25255/jss.2018.7.3.187.214

[4] Amjah, D.Y.P.H. (2014). A Study of Teachers' Strategies So Develop Students' Interest Towards Learning English as A Second Language. Procedia-Social and Behavioral Sciences 134, pp. 188-192. https://doi.org/10.1016/j.sbspro.2014.04.238

[5] Anderson, J. (2016). Why Practice Makes Perfect Sense: The Past, Present, and Potential Future of the PPP Paradigm in Language Teacher Education, Elted Vol. 19.

[6] Anwas, E.O.M., Steviano, I., Warsihna, J. (2018). The Use of Internet Content with Interest in Learning English on High School Student, Turkish Online Journal of Education Technology.

[7] Belal, A. (2014). Influence of Digital Social Media in Writing and Speaking of Tertiary Level Student. Thesis. BRAC University. Bangladesh.

[8] Blossom, J. (2009). Content Nation: Surviving and Thriving as Social Media Changes Our Work, Our Lives, and Our Future. Indianapolis, IN: Wiley Publishing.

[9] Bruns, A. (2010). Exploring the Pro-Am Interface between Production and Produsage. Proceedings of the Internet Turning 4.0: The Never-Ending Novelty of New Media Research? Hong Kong: QUT. 
[10] Buckingham, L., dan Alpaslan, R.S. (2017). Promoting Speaking Proficiency and Willingness to Communicate in Turkish Young Learners of English through Asynchronous Computer-Mediated Practice. System Vol. 65, pp. 25-37. https://doi.org/10.1016/j.system. 2016.12.016

[11] Byrne, D. (1976). Teaching Oral English. Longman. London.

[12] Chalim, Saifuddin dan Anwas, Oos M. (2018). Peran Orangtua dan Guru dalam Membangun Internet sebagai Sumber Pembelajaran. Jurnal Penyuluhan, Pascasarjana IPB. Maret 2018 Vol. 14 No. 1. Pp. 42 - 52. http://jurnal.ipb.ac.id/index.php/jupe/article/view/19558. https://doi.org/10.25015/penyuluhan.v14i1.19558

[13] Fagossa, Y. (2015). The Contribution of Facebook Groups in Improving English as a Foreign Language Writing Skill of 9th Grade Female Students at Public School in Jordan. Research on Humanities and Social Sciences Vol. 5 No. 24, pp. 94-98.

[14] Gray, C., Pilkington, R., Hagger-Vaughan, L., \& Tomkins, S. A. (2007). Integrating ICT into classroom practice in modern foreign language teaching in England: making room for teachers' voices. European Journal of Teacher Education, 30(4), 407-429. https://doi.org/10.1080/02619760701664193

[15] Godwin-Jones, R. (2016). Emerging technologies integrating technology into study abroad. About Language Learning \& Technology, 1.

[16] Hao, Y., Lee, K.S., Chen, S.T., dan Sim, S.C. (2019). An evaluative study of a mobile application for middle school students struggling with English vocabulary learning. Computers in Human Behavior, Vol. 95, pp. 208-216. https://doi.org/10.1016/j.chb. $\underline{2018.10 .013}$

[17] Hermida, A. 2010. From TV to Twitter: How Ambient News Became Ambient Journalism. Journal of Media and Culture, 13(2), 1-10.

[18] John, B., Thavavel, V., Jayaraj, J., Muthukumar, A., Jeevanandam, P.K. (2016). Design of Open Content Social Learning that Increases Learning Efficiency and Engagement Based on Open Pedagogy. TOJET: The Turkish Online Journal of Educational Technology, 15(1), pp. 20-32.

[19] Joosten, T. (2012). Social Media for Educators: Strategies and Best Practices. Jossey-Bass. San Francisco

[20] Juhana. (2012). Psychological Factors That Hinder Students from Speaking in English Class (A Case Study in a Senior High School in South Tangerang, Banten, Indonesia). Journal of Education and Practice. Vol.3 No.12: 100-110.

[21] Jurkovic, V. (2019). Online Informal Learning of English Through Smartphones in Slovenia. System 80, pp. 27-37. https://doi.org/10.1016/j.system.2018.10.007

[22] Kalogiannakis, M., \& Papadakis, St. (2018). An Evaluation of Greek Educational Android Apps for Pre-Schoolers. In Finlayson, O., McLoughlin, E., Erduran, S., \& Childs, P. (Eds.), Electronic Proceedings of the ESERA 2017 Conference. Research, Practice and Collaboration in Science Education, Part 4/Strand 4 (co-ed. Kalle Juuti \& Eleni A. Kyza, Digital Resources for Science Teaching and Learning), (pp. 593-603). Dublin, Ireland: Dublin City University. ISBN 978-1-873769-84-3. https://doi.org/10.1007/978-3-030-17219-0

[23] Kaplan, A. M., dan Haenlein, M. (2010). Users of the World, Unite! The Challenges and Opportunities of Social Media, Business Horizons 53, pp. 59-68. http://michaelhaenlein. eu/Publications/Kaplan, \%20Andreas\%20-\%20Users\%20of\%20the\%20world, \%20unite. pdf. https://doi.org/10.1016/j.bushor.2009.09.003

[24] Kemp, S. (2017). Digital in Southeast Asia in 2017. Accessed on July 14th 2018 from: https://wearesosial.com/special-reports/digital-southeast-asia-2017.

[25] Kemp, S. (2018). Digital in 2018: World's Internet Users Pass the 4 Billion Mark. Accessed on July 14th 2018 from: https://wearesosial.com/blog/2018/01/global-digital-report-2018. 
[26] Khan, I.U., Ayaz, M., Khan, S., dan Khan, M.F. (2016). Effect of Social Media on Enhancement of English Learning Proficiency at University Level in Khyber Pakhtunkhwa. Journal of Humanities and Social Sciences (IASET) Vol. 2, pp. 71-84.

[27] Khunaifi, A'am Rifaldi. (2015). Penggunaan Media Facebook untuk Meningkatkan Keterampilan Dan Motivasi Mahasiswa Dalam Menulis Recount Text. Pedagogik Jurnal Pendidikan, Volume 10 Nomor 1, pp. 51 - 61. file:///C:/Users/HUSER/Downloads/FKIP _Vol10_No1_part134_6\%20AAM\%20RIFALDY\%20KHUNAIFY.pdf. https://doi.org/ 10.33084/pedagogik.v10i1.599

[28] Larsen-Freeman, D. (2000). Techniques and Principles in Language Teaching. Oxford: Oxford University Press.

[29] Maghfiroh, Ana. (2016). Problema Pembentukan Karakter Berhahasa Asing Dikalangan Mahasiswa Program Study Pendidikan Bahasa Inggris. Jurnal Dimensi Pendidikan dan Pembelajaran. http://eprints.umpo.ac.id/1771/. https://doi.org/10.26877/mpp.v11i2.3362

[30] Nakata, T. (2017). Does Repeated Practice Makes Perfect? The Effects of Within-Session Repeated Retrieval on Second Language Vocabulary Learning, Article, Studies in Second Language Acquisition. https://doi.org/10.1017/s0272263116000280

[31] Nasrullah, Rulli. (2015). Media Sosial: Perspektif Komunikasi, Budaya, dan Sosioteknologi. Bandung: Simbiosa Rekatama Media.

[32] Page, R.E. (2012). Stories and Social Media: Identities and Interaction. New York: Routlegde.

[33] Papadakis, St., \& Kalogiannakis, M. (2017). Mobile educational applications for children. What educators and parents need to know, International Journal of Mobile Learning and Organisation (Special Issue on Mobile Learning Applications and Strategies), 11(3), 256277. https://doi.org/10.1504/ijmlo.2017.085338

[34] Papadakis S., Kalogiannakis M. \& Zaranis N. (2018). Educational apps from the Android Google Play for Greek preschoolers: A systematic review. Computers \& Education, 116, 139-160, https://doi.org/10.1016/j.compedu.2017.09.007

[35] Rahman, A., Atmowardoyo, H., dan Salija, K. (2018). Podcast Effects on EFL Learners' Listening Comprehension. ELT Worldwide Vol. 5 No. 2.

[36] Rokni, S.J.A. dan Seifi, A. (2013). The Effect of Dialog Journal Writing on EFL Learners' Grammar Knowlegde. Journal of Language and Linguistic Studies 9 (2), pp. 57-67.

[37] Sad, S.N. (2008). Using Mobile Phone Technology in EFL Classes. English Teaching Forum. Vol.4.: 34-40.

[38] Sakkir, G., Rahman, Q., dan Salija, K. (2016). Students' Perception on Social Media in Writing Class at STKIP Muhammadiyah Rappang, Indonesia. International Journal of English Linguistic Vol. 6 No. 3, pp. 1701-75. https://doi.org/10.5539/ijel.v6n3p170

[39] Samareh, M. dan Langroudi, J. (2018). Reading Comprehension: Blog Exposure in the English as a Foreign Language (EFL) Context in Iran, Translation Journal.

[40] Sirivedin, P., Soopunyo, W., Sriruantang, S., dan Wongsothorn A. (2018). Effects of Facebook Usage on English Learning Behavior of Thai English Teachers. Kasertsart Journal of Social Sciences 39, pp. 183-189. https://doi.org/10.1016/j.kjss.2018.03.007

[41] Supratman, Lucy Pujasari. (2018). Penggunaan Media Sosial oleh Digital Native. Jurnal Ilmu Komunikasi. Vol. 15, No. 1, 47-60. https://ojs.uajy.ac.id/index.php/jik/article/ viewFile/1243/1152. https://doi.org/10.24002/jik.v15i1.1243

[42] Richards, J.C. (2008). Teaching Listening and Speaking: From Theory to Practice. Cambridge: Cambridge Press University.

[43] Techin Asia. (2015). Statistik Pengguna Internet dan Media Sosial di Indonesia. https://id.techinasia.com/talk/statistik-pengguna-internet-dan-media-sosial-di-indonesia. (accessed on February 12nd 2018). https://doi.org/10.23969/paradigmapolistaat.v2i1.1662 
[44] Warsihna, J., Anwas, E.O.M. (2017). Curriculum model for improving quality of life for remote indigenous community (Research on baduy tribe of Banten province, Indonesia). Turkish Online Journal of Educational Technology.

\section{$7 \quad$ Authors}

E. Oos M. Anwas is a researcher in Center of Curriculum and Books, Ministry of Education and Culture, Jakarta, Indonesia. He is the main contributed author in this article.oos.anwas@kemdikbud.go.id

Yuni Sugiarti is a lecturer in UIN Syarif Hidayatullah Jakarta, Indonesia. yuni.sugiarti@uinjkt.ac.id

Anggraeni Dian Permatasari is a researcher candidate in Center of Curriculum and Books, Ministry of Education and Culture, Jakarta, Indonesia. anggraeni.dian@kemdikbud.go.id

Jaka Warsihna is a lecturer in Open University, Indonesia. Jaka.warsihna@ gmail. $\underline{\text { com }}$

Zulfikri Anas is a developer of curriculum in Center of Curriculum and Books, Ministry of Education and Culture, Jakarta, Indonesia. fikrieanas@yahoo.com

Leli Alhapip is a developer of curriculum in Center of Curriculum and Books, Ministry of Education and Culture, Jakarta, Indonesia. Leli.alhapip@kemdikbud.go.id

Heni Waluyo Siswanto is a researcher in Center of Curriculum and Books, Ministry of Education and Culture, Jakarta, Indonesia. heniwaluyo.hw@gmail.com

Rahmi Rivalina is a researcher in Center of Curriculum and Books, Ministry of Education and Culture, Jakarta, Indonesia. orivalina@yahoo.com

Article submitted 2019-08-21. Resubmitted 2019-11-17. Final acceptance 2020-01-16. Final version published as submitted by the authors. 